\title{
Effects of humans on nests and birds in and near two tropical reserves
}

\author{
Yoshika Oniki (*)
}

\begin{abstract}
Although birds are protected on the Agronomic Institute at Belém, and within a forest reserve at Manaus, there is some human destruction of easily located nests in open areas. Both adults and young of a tew species are occasionally captured for the cage-bird trade. Populations of most species seem unaffected, but one species of large seedeater has become rare.
\end{abstract}

Humans can affect nesting birds adversely, as for instance causing desertion in heron colonies (Werschkul, McMahon, and Leitschuh, 1976). In the tropics, direct loss of bird nests can occur in areas frequented by humans.

Nests can be collected for pleasure by local children, or by city children who visit recreational areas over the weekend or on vacations. Adult nesting birds are also hunted with guns or trapped for the cage bird trade. Besides this, other human activities can cause destruction of bird nests. The question is, can human actlvities near or in forest reserves significantly affect the ecology of birds in these areas? Here I present data on human effects on avian biology in and near two different reserves.

From March 1972 to May 1973, I studied breeding birds at Belém, Pará; and from June 1973 to August 1974, I visited Manaus, Amazonas, for the same purpose. Those studies will be reported elsewhere, but here I propose to examine the influence of man on the species of birds that they catch or from which they rob nests.

At Belém, the field work was conducted in and near the Aurá forest reserve of the Instituto de Pesquisas Agropecuárias do Norte (IPEAN). At Manaus, I studied nests mostly at Reserva Ducke of the Instituto Nacional de Pesquisas da Amazônia (INPA) and at Sítio I-iruçanga, across the highway from the front gate of the Reserva. Both in and near reserves, at Belém and Manaus, birds and their nests are protected; but there is some human destruction of easily located nests, especially in open areas and plantations near the reserves. Most forest nests are difficult to locate, and few local people venture deep into the forests, and for these reasons human destruction is less for forest-living species.

Tables 1 and 2 list the nests lost due to human interference. At Belém, nests destroyed by man were mainly in and near an experimental rubber plantation where such human activities as planting or pruning rubber trees, or cutting grass and weeds around them, were frequent. Several losses to man were in another study area, a pupunha (Guilielma gasipaes (H. B. K.) Bailey, Palmae) palm grove, where workers entered now and then to clear undergrowth or to collect the palm fruits. Few losses were recorded in Aurá Forest Reserve itself. Some high percentages are due to small sample sizes, but for species like Common Ground-Dove, (Columbina passerina), and BlueBlack Grassquit, (Volatinia jacarina) with more than 5 nests each, we can see that the losses to man were minor. For species actively hunted by man for the cage-bird trade, such as PaleBreasted Thrush, (Turdus leucomelas)), Variable Seedeater (Sporophila americana) and Yellow-bellied Seedeater (Sporophila nigricol(is), there were higher losses.

At Manaus, losses of nests to humans were all at the forest border and none within the forest itself. Total losses to humans were lower than at Belém, for fewer workers and others use the Manaus reserve and the nearby sítio.

Causes of nest destruction include bulldozers scraping new areas to obtain gravel, tractors cutting high grass, men with machetes

(*) -219 W. Plata St., Tucson, Arizona 85705 
clearing rubber plantations or grassy areas, passersby stepping on the nest or cutting it down for no obvious reason, and children and adults hunting with guns for pleasure or for food. In general, the nest destruction does not seem significant, although it does raise mortality rates slightly. Since most of species affected by human interference nest mostly in areas created by human activity, most are benefiting more than they lose from these activities. For instance, Blue-Black Grassquits and Common Ground-Doves have to nest in low growth, which in the climatic conditions at Belém would scarcely exist if man did not cut vegetation every year.

A more serious effect of man at Belém is on adults or young of a few species that are captured for the cage-bird trade. The main species preferred are seedeaters, Lesser SeedFinch, Oryzoborus angolensis (locally called curió), Sporophila americana (coleira) and Sporophila nigricollis (papa-arroz), all Fringillidae. Several species of thrushes are captured,

TABLE 1

Nests destroyed by man - Belém, 1972-1973.

\begin{tabular}{lcr}
\hline Species & $\begin{array}{c}\text { Number } \\
\text { nests found }\end{array}$ & $\begin{array}{r}\text { Number } \\
\text { destroyed } \\
\text { by man }\end{array}$ \\
\hline
\end{tabular}

Columbina passerina

Otus choliba

Caprimulgus nigrescens

Glaucis hirsuta

Dryocopus lineatus

Manacus manacus

Pitangus sulphuratus

Camptostoma obsoletum

Turdus leucomelas

Coereba flaveola

Ramphocelus carbo

Saltator maximus

Volatinia jacarina

Sporophila americana

Sporophila nigricollis

All other nests (65 species)

TOTAL ( 80 species)

Percentage but the nest most easily found is that of Turdus leucomelas. These birds are mainly captured for their beautiful songs, since they are not brightly colored. Local people seldom showed me such nests, for they preferred to sell the young. When I did find nests, they were often robbed. Most species are still common despite this constant destruction, but one species of large seedeater, the curió, has become rare in the Institute. This species, like many seedeaters, is captured in an "alçapão" trap with a "chama" or lure. The trap works either by attracting a territorial rival to the bird in the trap or by a birc coming for food when it sees the bird in the trap feeding. The curió is so popular a song bird and so hunted that every time a wandering bird comes into the Instituto it is soon captured. Since this is the largest species of seedeater at Belém, this leaves a niche vacant in the local seedeating guild.

As well as effects of nonscientists on birds, scientists themselves affect birds in reserves. E. O. Willis (pers. comm.) found that scientists cutting areas adjacent to the Aurá reserve at Belém sent temporary floods of displaced birds (especially White-Backed Fire-Eye, Pyriglena leuconota) into the reserve. Workers on arbovirus and mosquitoes within the reserve regularly killed colonies of army ants (Eciton burchelli) entering their cabin, creating an "ecological vacuum" because of

TABLE 2

Nests destroyed by man - Manaus, 1973-1974

Species $\quad \begin{gathered}\text { Number } \\
\text { nests found }\end{gathered}$\begin{tabular}{c}
$\begin{array}{c}\text { Number } \\
\text { destroyed } \\
\text { by man }\end{array}$ \\
\hline
\end{tabular}

Thalurania furcata

Galbuia dea

Myiozetetes cayenensis

Turdus leucomelas

Coereba naveola

All other nests (78 species)

TOTAL (83 species)

Percentage

$\begin{array}{rl}1 & 1 \\ 1 & 1 \\ 3 & 1 \\ 1 & 1 \\ 9 & 1 \\ 157 & 0 \\ 172 & 5 \\ 100 & 3\end{array}$


loss of this important predator; as a result, local colonies of "tracuá" (Camponotus sp.) ants became unusually abundant and several birds (especially Pyriglena leuconota and Black-Spotted Bare-Eye, Phlegopsis nigromacLlata, which follow army ants) deserted the area around the cabin. Willis is reporting elsewhere on these effects.

\section{ACKNOWLEDGEMENT}

This project was made possible thanks to the financial support from Conselho Nacional de Desenvolvimento Científico e Tecnológico and National Science Foundation, Grant GB32921. E. O. Willis helped with field work and with the manuscript. Peter Westcott also helped with the manuscript. The directors of the Instituto Nacional de Pesquisas da Amazônia (INPA) and Instituto de Pesquisas Agropecuárias do Norte (IPEAN), permitted the use of their facilities and of the Reserves. Also, Sr. Mário Corofino, owner of Sítio I-iruçanga, kindly permitted the study of nests in his property. This paper was presented at the II International Conference of Tropical Ecology, at Caracas, Venezuela in 1973.

\section{Sumário}

$\mathrm{E}$ focalizado o efeito do homem em aves e seus ninhos dentro e próximo de duas reservas tropicais. Os resultados demonstraram que a influência do homem na ornitofauna dessas áreas é míni. ma. As espécies de aves em áreas abertas e plantações foram as mais afetadas. Entretanto, um fringilídeo -o curió -, por ser mais procurado e ca. çado por seu belo canto, é raro na área,estudada em Belém.

\section{LITERATURE CITED}

Werschiul, D.F.; McMahon, E. \& Letrschum, M.

1976 - Some effects of human activities on the Great Bluc Heron in Oregon. Wilson Bull., 88 : 660-662. 